\title{
The Perfect Storm: Stress, Anxiety, and Burnout in the Secondary School Music Classroom
}

\author{
John L. Vitale \\ Nipissing University
}

\begin{abstract}
This study investigates teacher stress, anxiety, and burnout through my experience teaching music in a suburban Toronto secondary school between 2002 and 2008. Primary data sources include a rich collection of journal entries I have written over a six-year period, which were retrospectively analyzed in this study. Hence, this study is principally rooted in reflective practice. In addition, this study is informed through autobiographical and phenomenological lenses. These other two lenses have allowed me to incorporate secondary source data (anecdotal notes, emails, text messages, and video footage) that were repurposed for this study. Findings have exposed two principal thematic representations from the data, namely; (a) those that directly or indirectly addressed extracurricular performances, and (b) fear of failure. Reexperiencing my experience has been exceedingly therapeutic and cathartic for me, providing insight and transparency into the demanding nature of music pedagogy at the secondary school level. In addition, findings have helped me to refine and develop my current and future pedagogy as a teacher educator.
\end{abstract}

Keywords: reflective practice, autobiographical, teacher stress, anxiety, and burnout, music education

John L. Vitale is an Associate Professor in the Schulich School of Education at Nipissing University (Brantford Campus). He teaches Music Education and Curriculum Methods in the Bachelor of Education Concurrent Program, as well as general Research Methods in the Master of Education Program. With over a decade of experience in the high school music classroom, Dr. Vitale's principal research interests lie in music education.

Email: johnv@nipissingu.ca 


\section{Introduction and Purpose}

I consider myself fortunate to have had the experience of teaching secondary school music for well over a decade. Despite the numerous successes that I have had during this experience, stress and anxiety slowly began to imbue my daily teaching. In the end, I exhibited many signs of teacher burnout. The most valuable coping mechanism for me during times of elevated stress and anxiety, however, was reflective practice. It is no surprise, therefore, that the largest number of reflections that $I$ have written during my entire educational career coincided with a six-year period of teaching music in a suburban Toronto secondary school (from 2002 to 2008), where I experienced extreme levels of stress and anxiety. I will refer to this particular secondary school as Melody High (a pseudonym) throughout the duration of this article.

As an individual who made the switch to teacher educator, I quickly realized that the sixyear period of teaching at Melody High provided me with an extensive pool of rich and detailed primary data. Hence, I started the arduous process of sorting and categorizing my reflections about a year ago. As I started to comb through the primary data, I discovered many other secondary data sources (anecdotal notes, emails, and video footage, for example) that helped paint a clear picture of my six-year tenure at Melody High. In sum, the retrospective investigation of these stress, anxiety, and burnout-laden data sources is the principal purpose of this study.

\section{Contextual Framework: The Perfect Storm}

Prior to my arrival in 2002, Melody High had been in operation for nine years with a scant and paltry music program and not one wind instrument in stock. The lack of financial support and a very low level of music education advocacy created a revolving door of music teachers. In its 10th year of operation, a new administrator finally recognized this tragedy and wanted to right the ship. He started by hiring an experienced music teacher (myself) as well as injecting $\$ 100,000.00$ into the program over a 4-year period to purchase wind instruments. With so much financial commitment and a series of failures before me, there were very high expectations placed upon my shoulders to breathe life into a dead music program. This huge responsibility was exacerbated by the fact that $95 \%$ of grade 9 band students entered into this school as complete beginners on wind instruments, as they came from feeder schools where no instrumental music education transpired. Looking back now, it was the largest challenge of my teaching career to date. In many ways, it was the perfect storm -- a storm that ultimately spawned extreme levels of stress and anxiety, which eventually lead to burnout.

\section{Literature Review}

Teacher stress has been the subject of numerous research studies over the years. Kyriacou (2001) describes teacher stress as "the experience by a teacher of unpleasant, negative emotions, such as anger, anxiety, tension, frustration or depression, resulting from some aspect of their work as a teacher" (p. 28) Chang (2009, p. 193) connects teacher stress to burnout: "Habitual patterns in teachers' judgments about student behavior and other teaching tasks may contribute significantly to teachers' repeated experience of unpleasant emotions and those emotions may eventually lead to burnout." What exactly is burnout? Stern and Cox (1993) describe teacher burnout as overextending oneself to the point that the teacher loses excitement for the subject matter. 
Specifically within music education, teacher stress and burnout have received much attention over the years. In fact, Haack and Smith (2000) indicate that teaching music is "the most challenging job in the teaching profession." (p. 24) Similarly, Hodge, Jupp \& Taylor (1994) indicate that over half of music teachers consider their subject the most difficult to teach, and no music teachers consider their subject area the easiest to teach. Moreover, Carson (2006) argues that music teachers are more prone to burnout. Hodge et al (1994) found that music teachers experienced more job-related stress than math teachers did.

In general, high levels of stress and eventual burnout within music education is a serious situation for the profession as a whole, as burned out teachers are prone to more sickness and absenteeism (among others), which significantly affects the overall quality of teacher instruction and ultimately student learning (Hodge et al, 1994). Stern and Cox (1993) further elucidate on this point:

A burned-out teacher will tend to display almost no enthusiasm for the subject matter or for teaching. He or she will also not be receptive to answering questions or responding to student needs, and as a result, will not encourage students to learn. (p. 2)

Poor pedagogy and minimal student learning resulting from stressed out and burned out music teachers is over and above the fact that music education is constantly striving to increase its profile and importance within mainstream public education (Scheib, 2002; Jorgensen 2003; Pio, 2007), which adds significantly more stress to the lives of music educators. English teachers, for example, do not have to worry about student enrollment, as English is a compulsory subject for all students at the secondary school level in Ontario. Music, however, is an optional subject, and music teachers must simultaneously teach and market their programs -- a very challenging and stressful task indeed, particularly when curriculum can be constraining.

Ultimately, teacher stress and burnout is an occupational hazard that can be seriously debilitating and inevitably warranting treatment (Hamann, 1990; Hamann \& Gordon, 2000). In fact, Hamann \& Gordon (2000) argue that teacher burnout typically follows a five-step pattern, namely; (i) honeymoon stage; (ii) fuel shortage; (iii) chronic symptoms; (iv) crisis; and (v) hitting the wall. Such a pattern is indicative of the widespread and predictable phenomenon of teacher burnout.

Why are so many music teachers burning out? There are numerous factors, but the following four factors continuously emerge over and over again in multiple studies, namely; (i) a dearth of resources, (ii) minimal budgets, (iii) heavy workloads, and (iv) large class sizes (Hamann \& Gordon, 2000; Stern \& Cox, 1993; Hamann, Daugherty, \& Mills 1987; and Hamann, Daugherty \& Sherbon, 1988). Moreover, the literature has identified four principal groups of music teachers that are suffering from burnout. The first group is music educators right at the beginning of their teaching careers, which has been referenced by Jorgensen (2008): "Without adequate mentoring and workload reduction or amelioration, and with low pay, it is not surprising that so many music teachers suffer burnout or quit teaching within a few years, and thus are lost to the profession." (p. 84) This is also confirmed by Ryan (2009) who states that: "The many facets and stresses that come with the realities of the job are, unfortunately, reflected in the high rate of burnout among young music teachers within the first few years on the job." (p. xii) Teaching, then, becomes more about surviving rather than learning how to teach more effectively (Wideen, Mayer-Smith, \& Moon, 1998). Moreover, new music teachers feel isolated 
during their first year of teaching, which contributes to high levels of stress and premature burnout (Ballentyne, 2007).

A second group of music teachers that are susceptible to burnout are "often the most productive, dedicated, and committed in their fields" (Hamann, Daugherty, \& Mills, 1987, pp. 128-129). Music teachers from this group are typical Type A personalities and often seek perfection and excellence in everything they do. This is consistent with Friedman and Rosenman's (1974) research, which indicates that individual's with Type A personalities are often the victims of stress and more susceptible to heart attacks. Moreover, Bramhall \& Ezell (1981) cleverly state that "you have to have been on fire to burnout." (pp. 128-129).

The third group that is more susceptible to burnout is male music educators. In fact, Hamann, Daugherty \& Sherbon (1988) and Gordon (1997) have indicated that male music teachers suffer from the problem of burnout at significantly higher rates than their female counterparts do. Gordon (1997), who reported that inner-city teachers experience greater stress, particularly regarding student discipline and motivation, over their sub-urban and rural colleagues, has identified the fourth group.

\section{Theoretical Framework}

Given that all of the data are my own words (either written or spoken), this study is essentially qualitative in nature with a richly descriptive product (Creswell, 2009; Merriam, 2002) rooted in reflective practice. Donald Schön's (1983) publication The Reflective Practitioner was instrumental in coining the term "reflective practice," even though elements of reflective practice date back to the work of Dewey (1933). Schön (1983) argues that the basic premise of reflective practice is to engage in a process of continuous learning by reflecting on action. One of the most effective ways to engage in meaningful reflective practice is through journal writing. Specifically, journals allow the writer to break routine ways of thinking, develop reflective judgment, facilitate self-exploration and personal growth, and acquire solutions (Andrusyszyn \& Davie, 1997; Mitchell \& Coltrinari, 2001; Moon, 1999).

Although reflective practice is the principal theoretical lens, other lenses, namely autobiographical research and phenomenology, also inform this study. The autobiographical lens is somewhat paradoxical (as the researcher studies his/her own experiences), but it has been gaining in popularity (Tenni, Smyth, \& Boucher, 2003). In addition, autobiographical research reveals many "patterns in experience" not easily demonstrable in other types of research frameworks (Bullough \& Pinnegar, 2001, p. 16), making it ideal and sublime in many respects (Gusdorf, 1980). From an educational perspective, autobiographical research can "help both teachers and students redefine their educational experiences on their own terms and in their own voices" (Pinar \& Pautz, 1998, p. 72). Moreover, autobiographical research by an educator leads to his/her "nuanced perspective on interpreting the world of teaching and learning" (Vasconcelos, 2011, p. 416).

Since I am interested in my own life experiences, this study has a phenomenological lens (Moustakas, 1994; Trochim, 2006). According to Pinar, Reynolds, Slattery, \& Taubman (1995), phenomenology is "a disciplined, rigorous effort to understand experience profoundly and authentically" (p. 405). Moreover, reflective practice is the primary process of any phenomenological inquiry (Mostert, 2002). Similarly, Aoki (1988) and Grumet (1988) have praised autobiographical research as legitimately phenomenological in nature. 


\section{Data Collection}

\section{Methodology}

The wide variety of reflections emanating from my last 6 years of teaching at Melody High are representative of how I experienced the world of music teaching, and are the primary source of data for this study. I classified my data into three categories. The first category consists of 28 journal entries, while the second is a large melting pot of anecdotal notes captured in various forms, such as my teacher daybook (lesson plans), post-it notes, rehearsal notes, and even restaurant napkins. The third category is electronic in origin, including qualitative data captured from emails, text messages, as well as conversations/comments recorded in video footage. In terms of the video footage, the Music Student Council at Melody High filmed each and every performance put on by the Music Department, which always included commentaries by students, other teachers, and of course, myself. I categorized the data into two strands. Primary data sources are journals as intended to be reflective in nature and in the first strand category. The second strand, however, is secondary source data, repurposed from the original intent, such as the anecdotal notes, emails, and video footage, for example. Such diversified sources of both primary and secondary data (as referred to above) are now "more and more commonplace" in autobiographical research according to Lagemann \& Shulman (1999, p. xvi).

\section{Data Analysis and Findings Presentation}

With such a diverse range of data sources, data analysis can become a very complicated and arduous process. The most commonly used data analysis method in qualitative research is thematic analysis (Braun \& Clarke, 2006), which is a quest for themes that materialize as being important to the description of the phenomenon being studied (Aronson, 1994; Daly, Kellehear, \& Gliksman, 1997). This approach involves the identification of themes through "careful reading and re-reading of the data" (Rice \& Ezzy, 1999, p. 258) and is essentially a type of pattern recognition within the data itself. The task of the researcher, therefore, is to identify a limited number of themes, which adequately reflect their textual data (Hewitt \& Cramer, 2008). All of the data sources for this study involved words (both written and spoken). Journals and anecdotal notes were already in written form, and video footage of me speaking was transcribed. Once all of the data was assembled, traditional coding of key words, phrases, and expressions was conducted -- no software was used during this process. Initially, multiple codes emerged from the data. Through subsequent analyses, these codes were reduced to larger themes through the process of eliminating redundancies (Creswell, 2012).

\section{Findings}

The findings of this study can be summarized by the following two principal thematic representations from the data, namely (a) extra curricular performances and (b) fear of failure. In this section, I will elucidate and explain each of these themes with the support of primary data source passages and secondary repurposed data. The extrapolation of these two themes will provide insight into the extreme levels of stress and anxiety that I was experiencing at Melody High, which eventually lead to teacher burnout. 


\section{Theme One: Extra Curricular Performances}

A number of reflections directly and indirectly pointed to the theme of extra-curricular performances. Despite a full time teaching timetable, the entire success of the music program rested on extracurricular performances, which usually necessitated a multitude of early morning, lunchtime, and after school rehearsals, as well as numerous phone calls, emails, and late night planning sessions. Moreover, concert dates for each school year were set in June of the previous year in order to avoid conflict with other departments within the school as well as local community organizations that were holding events in the school gymnasium. These fixed dates, therefore, put enormous pressure on me right from the first day of classes in September. Although these predetermined dates kept me focused and on track in my teaching, it was simultaneously very stressful. There was no margin for error, no extension of concert dates, and no realistic opportunity to bow out without embarrassment. This stressful situation was exacerbated with grade 9 beginning band classes, where students did not know how to play a single note on day one in September. Yet, they were scheduled to play at least two songs in the Holiday concert in mid-December. Practice, prepare, practice, prepare, and play the concert; this was the very nature of my music program (Bernhard, 2011). These sentiments are captured in a reflective journal entry that I wrote on September 4, 2007:

There is nothing like the first day of school! Even though I have been through this routine several times, I never feel totally prepared. In large print, I wrote the words "Music Night: December 13, 2007 - mandatory performance for all students" on the blackboard before classes started this morning. I could feel my heart beating as I was writing this date on the blackboard. Deep down in my core, I just knew how much work it would take to get my students ready for this concert. An entire semester worth of teaching, before and after school rehearsals, phone calls, meetings, blah, blah, blah, -- all of these things would play over and over in my mind in just a few seconds. Sure enough, as each of my classes came in throughout the day, I could see and hear scrums of conversations about the date on the board. Some of these conversations were pleasant, and some of them were not. The bottom line is that summer is over, and it's time to prepare for Music Night in December. My job has become far too predictable and I must admit that I am not looking forward to all of the work that lies ahead. Music Night is just over 3 months away and I am already thinking about it and preparing for it - go figure!

The stress and anxiety of the looming concert date peaked during the last 2 weeks of preparations. Students were often not ready, which necessitated a number of precautionary measures. I often had to rewrite charts for students-simplifying rhythms and raising/lowering specific notes. This was usually done at the dinner table and often interfered with familial obligations as well as my relationship with my spouse. A reflective journal entry from December 5, 2005 summarizes these emotions:

My wife asked me at the dinner table last night if I was married to her or to my students. Although she was joking and generally speaking is very understanding, I can readily detect the stress in our relationship, which continues to steadily rise the closer I get to Music Night. In recent years, she has even asked me if my salary is worth all of the extra work that I put in, especially when many other teachers go home right after the final bell 
of the day and make just as much money as I do. I must admit that I do agree with her, but I only know two speeds - fast or slow. Preparing for Music Night can only be done at full speed ahead.

Moreover, I would have impromptu after school sectionals during the 2 weeks leading up to Music Night, which were over and above the heavy rotation of before and after school rehearsals already scheduled. These extra sectionals were indicative of the extra workload that would manifest itself during the last 2 weeks before the concert, exponentially adding to already high stress and anxiety levels. These sectionals were necessary when a certain instrument had a difficult part within one of the songs that we were scheduled to perform. I can specifically recall an incident 2 days before the spring concert in May of 2006, where I had not stopped all day long. I had an early morning rehearsal with Senior Band, followed by two regular classes, a lunch hour Junior Band rehearsal, and two other regular classes to finish the school day (my prep had been taken away during last period, as I had to cover for a teacher who went home sick that afternoon). Realizing that I did not eat anything all day long, I was suffering from a headache, dizziness, and extreme fatigue, only to face the fact that I had a Junior Band trumpet sectional (which was scheduled that day over lunch hour) starting right after school. Since my classroom desk was completely upside down, I searched for a piece of paper to write a note for my Junior Band trumpet indicating that I would be about 10 minutes late. The only thing I could find was a napkin from the school cafeteria, which I used to write my note and posted on the front of the music room door. The note said: "Junior Band Trumpet Sectional: Please do not leave, I will be about 10 minutes late. I need something to eat or else I will die. Your famished music teacher, Mr. Vitale." Although somewhat comical in nature, this short but valuable reflection (I still have the napkin today) clearly illustrates how stressful my life was just before Music Night. So stressful, in fact, that I obviously ignored basic good health practices (such as eating), and my body suffered as a result.

Stress, anxiety, and burnout often manifest themselves through the physical body in a variety of forms (Rada \& Johnson-Leong, 2004). This happened to me on a number of occasions, but nothing more pronounced than the events of December 2006. In addition to having a regularly scheduled Music Night during the second last week of classes before the holiday break, I also had six offsite performances with the Senior Band scheduled in the last week before the holiday break. A week before Music Night, I was teaching band and I started seeing stars (blacked-out) while conducting. Sensing something was clearly wrong, I gave the class a fiveminute break so I could get some fresh air outside, but the same thing happened again once class resumed. Luckily, I made it through the rest of the class and I traded my lunch hour rehearsal for a trip to my doctor who was only 5 minutes away. After begging and pleading with the receptionist, my doctor gave me a quick check-up and was startled to find out that my blood pressure was sky high. Fearing a stroke or possible heart attack, he ordered that I stay home for the next 2 weeks. I called in sick for the rest of the day, but had some important decisions to make. I had Music Night in a week and over 300 tickets had already been sold, not to mention the six off site performances scheduled in 2 week's time. Here is a journal excerpt from December 7, 2006 that captures the very essence of my predicament:

It feels as if my whole life is falling apart. My health is suffering because I am taking my job too seriously. Although my doctor has asked me to stay home for two weeks, how can I cancel Music Night? We have worked so hard and the students would be disappointed. 
My wife thinks I am crazy if I don't take the doctor's advice. She is worried about my well-being and the well-being of our two children should something happen to me. I think I will definitely cancel the six off-site performances scheduled for two-week's time. As far as Music Night is concerned, I will still run with it. I will take three days off and return two days just before Music Night to run through final rehearsals. The students are $85 \%$ of the way there and I still think they can successfully do the show.

Here is another journal excerpt, post concert, 7 days later (December 14, 2006) that truly captures the essence of my elevated stress, anxiety, and burnout:

Music Night came and went just the same. It was not as good as I thought it could be, but truth be told, it was still a great show. Life is strange, my wife is still upset with me and I also get the feeling my Principal is upset with me for cancelling the six shows at the local elementary schools. He is a first year principal and he really wanted me to do these shows to attract students to our school. The students are also upset, as they wanted to perform at these schools, particularly since they came from these schools. It is a great opportunity to go back to their former elementary schools and show their former teachers how well they can play. Life is strange, my wife is upset at me for performing, and my students and principal seem upset at me for not performing. I cannot win. This job is getting too difficult for me. Music teaching used to be so much fun, now it seems like heavy work that I cannot handle. I feel like I have very little to give anymore.

\section{Theme Two: Fear of Failure}

Although the primary and secondary source data found in this section deal with extracurricular performances, they are imbued with a clear sense of fear. Even when I reread these excerpts many years later, an evident sense of fear, trepidation, and uneasiness came over me compared to the other excerpts in the previous theme. Hence, a new theme - fear of failure - clearly emerged from the data. I can specifically remember the spring of 2006, where the dress rehearsal did not go well, particularly with Senior Band. My wife had sent me a text message right after school asking me how the dress rehearsal went. I responded with the following text message: "The buggers were horrible. I am not confident about our chances this evening." My wife responded back: "Everything will be fine; don't worry." The performance that evening was satisfactory, but not before four hours of trepidation and fear. This fear was even captured in video footage taken by Music Student Council before the concert. A student asked me how I was feeling and I simply responded: "Nervous, I am really, really nervous about the performance this evening."

Even when I was not conducting on Music Night and had a chance to catch my breath during a solo or ensemble performance, fear still manifested itself. I can specifically remember the spring concert in 2007 where a senior student (Linda) did a trumpet solo to a backing CD track. She struggled from the very first note, exhibiting erratic breathing and poor tone, and halfway through the song, she completely stopped and walked off the stage in tears. Although the audience cheered her on to return to the stage and redo her song, she never did. I was mortified when this student left the stage and fearful for the student. My journal the day after the concert (May 18, 2007) summarizes this incident: 
I've never felt as bad for a student as I did for Linda last night when she walked off the stage. She had played so well in class and has lots of performing experience, but she just didn't have it last night and flubbed too many notes. What a horrible way to end your high school music career-crying and walking off the stage. After the show, I asked her what had happened, and she just said the notes were not coming out and she didn't know why. She was clearly upset and very emotional. Since Linda's performance was early in the program, I was extremely fearful that there was bad karma in the air, and that something else would go wrong last night. Even though everything else ran smoothly, I was scared to death for the remainder of the show. It felt as if the weight of the world was taken off my shoulders when the show was over. It's amazing how one bad performance can affect my own feelings and psyche.

Every year, Melody High held their annual graduation ceremony off-site at a local banquet centre, as the school auditorium could not handle the large number of guests due to the sizeable student body. Every year, the Senior Band performed a number of songs for a very large audience of over 1,400 guests during the evening of graduation. Although I had a small crew of students who helped me to transport some of the bigger instruments (e.g., bass drum, timpani, etc.) right after school, the remainder of the band provided their own transportation to the event every year, which started at 7:30 p.m. For six consecutive years on the evening of graduation, I feared students coming late, which was arguably the largest community event of the year with such notable attendees as the mayor, the superintendent and director of the school board, and local media. The hour leading up to the first note was dreadful every year as there would always be a few students showing up in the very last minute. The journal entry of October 19, 2005, the day before graduation, captures the theme of fear.

Well, we have Grad tomorrow night, and all the big wigs will be there. No matter how many times I tell the students to arrange their transportation and show up early, there are always a few students that show up late or right before we are scheduled to start, which really scares me. I get very nervous, start to sweat, and my ability to conduct becomes compromised.

Every year, the holiday Music Night would always be held during the last week or two of scheduled classes just before the Christmas break. Year after year, there were a few students who would give me one or two weeks warning that they could not play in the holiday concert because of some sort of family commitment. It always seemed that these students were the top players within their section, and their section always sounded horrible without them. Even though I always bought into the "show must go on" mantra, it was like a dagger in your heart when these students informed me that they would not be showing up. There was always fear that a particular song would not go over well if a specific student was absent. The journal entry of December 6, 2004 clearly captures this fear:

What a busy day! Our concert is next week and things are really in full swing. Mike, the best trumpet player in the Senior Band, informed me today that he will not be able to make Music Night as his family has some sort of church function that evening. No matter how hard I pleaded with him, he said that he could not make it. There is one song we are performing (Overture Espagnol) that really relies on the first trumpet part, and Mike is 
really the driving force behind the first trumpet section. I may have to pull the song from the program, and, go figure, the programs have already been printed. Otherwise, I will be terrified to perform the song.

Similarly, I would have numerous skirmishes with other teachers at Melody High whenever a performance necessitated one of my students from missing other classes. Although some teachers were very cooperative, many teachers resisted and resented me withdrawing students from their classes, even when I had the principal's endorsement. Students were often put in the middle of this ridiculous power struggle, and they often did not show up to off-site performances during the school day as they were afraid of losing marks in their other subjects, particularly senior students who were university bound after graduation. This would usually happen the day or two before a scheduled performance, and the fear of performing without specific students always reared its ugly head. The following excerpt from my daybook on December 17, 2007 under the heading of "After School" captures how these last-minute absences weighed heavily on my mind. "Final rehearsal for Christmas performance at the mall on Thursday. I wonder who is not showing up this time?" The following email was sent to my principal in December of 2007, which addresses this very issue:

\section{Hello Ryan,}

I am surprised at the large number of teachers who do not approve of me withdrawing students out of regularly scheduled classes for a musical performance. All of the planning, time, and effort that goes into a musical performance can easily be compromised when a few students are absent, making my role as band director very frightening at times. I think we need to develop a school policy for such situations - not just for music, but also for sports and any other extracurricular event that necessitates students being withdrawn from classes. If we had such a policy, I could not only work with it, but it would also level out the playing field for all teachers. It is unfair that students are often forced to choose between teachers and classes.

\section{Discussion and Meaning Making}

In this article, I have offered a candid and honest look into my life experiences at Melody High (Clandin \& Connelly, 2000, p. 20). There are essentially two aspects of my reflective journey. The first was reliving specific moments in time during my tenure at Melody High through rereading journals, emails, and re-watching videos, for example. The second aspect was noticing how my reflections had changed and evolved over a six-year period. The two aspects are duly represented by the two themes of (i) extracurricular performances and (ii) fear of failure.

Ultimately, many findings were consistent with the literature in the field of stress, anxiety, and burnout. I certainly experienced many unpleasant and negative emotions (Kyriacou, (2001) as well as emotional exhaustion (Chang, 2009). I have had the experience of teaching subjects other than music early on in my career, and I must concur with Haack and Smith (2000) and half of the participants in the Hodge et all (1994) study that teaching music is the most challenging/difficult to teach. Not surprisingly, I certainly agree with Carson (2006) that music teachers are more prone to burnout, as well as sickness, absenteeism, and diminished enthusiasm (Hodge et al, 1994; Stern \& Cox, 1993). 
By the end of my six-year tenure at Melody High, findings uncannily supported Hamann \& Gordon's (2000) five-step burnout pattern. There is no doubt that I had a honeymoon stage (step one) during my first two years. In fact, I left another school board to take the position at Melody High, and I relished the opportunity to build a program at a school where multiple teachers before me had failed. As I entered my third year at Melody High, the program began to expand rapidly. With no other teacher in the music program to assist me, I was essentially working much harder and certainly felt a significant lack of energy in my daily teaching, which corresponds perfectly to Hamann \& Gordon's (2000) second step of fuel shortage. By the fourth year, I clearly experienced step three (chronic symptoms) and step four (crisis). I was blackingout in class and I had severe hypertension. The doctor ordered me to stay home. This resulted in me cancelling some scheduled performances and simply dreading my job. The final stage (hitting the wall) was indicative of the fact that I just could not do the job anymore, and I eventually took a three-year leave of absence, which ultimately resulted in a resignation from the school board.

In terms of the four factors that perpetuated music teacher burnout -- (i) dearth of resources, (ii) minimal budgets, (iii) heavy workloads, and (iv) large class sizes (Hamann \& Gordon, 2000; Stern \& Cox, 1993; Hamann, Daugherty, \& Mills 1987; and Hamann, Daugherty \& Sherbon, 1988), findings were consistent with one out of the four (heavy workloads). Even though data did not specifically address large class sizes, I can certainly concur that my class sizes at Melody High were exceedingly large.

When it came to the four identified groups of music teachers that were susceptible to stress, anxiety and burnout, findings clearly aligned with two of the four groups. As a veteran teacher, I could certainly not relate with the first group of beginning teachers burning out. To the contrary, I had more time and energy in my first five years of teaching than I ever did while teaching at Melody High. My findings, however, markedly and keenly echoed the second group - the Type A personality teacher that was prone to eventual burn out. It was very clear to me then, and now, that perfection and excellence were the very measuring stick for my music program. Although I did not suffer a heart attack as Friedman \& Rosenman (1974) have suggested could happen, I certainly suffered severe hypertension and as previously mentioned, which could have lead to a heart attack. Moreover, Greenberg (2002) indicated that stroke and coronary heart disease have been associated with stress because of increased blood pressure.

In addition, I suffered many other physiological symptoms (such as stomach cramps, severe migraines, and fatigue) that are consistent with the results of a longitudinal study on teacher stress conducted by Burke, Greenglass, \& Schwarzer (1996). Although triggers for stress, anxiety, and burnout vary from person to person, the most critical aspect for a teacher's wellbeing is the recognition of such triggers, something I was not able to do until my own doctor ordered me to stay home for 2 weeks. Even then, I did not fully comply with my doctor's order. Music teachers ultimately need to find balance between achieving results and managing stress; otherwise, burnout is inevitable. Moreover, there is an awkward and compromising risk (LeeTreweek \& Linkogle, 2000; Mercer 2007) in exposing the state of my health during my time at Melody High, which is now publicly accessible for former colleagues, students, and parents.

Moreover, findings verified the third group (male music teachers suffering from burnout significantly more than females) as referenced by Hamann, Daugherty \& Sherbon (1988) and Gordon (1997). The fourth trend (inner-city teachers experience greater stress over their suburban and rural colleagues) does not apply on paper since Melody High was in a suburban setting. Having taught in two inner city schools for over 5 years, however, I can honestly say that Melody High did have many inner-city characteristics, including student drug use, lack of 
parental involvement, and student apathy (Erskine-Cullen \& Sinclair, 1996). For such reasons, Melody High was considered one of the least desirable places to work at by virtually all teachers within the larger school Board. Hence, I would argue that this category was to a certain extent represented in my findings.

My reflections from Melody High that exuded the theme of fear were intimately connected to situations when I was vulnerable and susceptible to public scrutiny. When key students did not show up for a performance, for example, I was always scared to death about the quality of the performance, as all fingers would eventually be pointed at me as the musical director and conductor. I even felt this sense of fear when I did not have the baton in my hand. When I think about how horrible I felt for Linda and her flubbed trumpet solo, I was ultimately concerned more about how her bad performance reflected my own teaching and aptitude. I guess to a certain extent this reveals a sub-theme of selfishness in my own teaching that I did not know existed. As an educator who gave every ounce of time and energy that I had to my students and my program, I have never once thought for a second that there was an element of selfishness to my teaching until I completed this study, which is inherently one of the great advantages of reflective practice. This tells me that there are many layers and strata to who we are as professionals in the classroom. Much like geology, it takes a lot of time and movement for these layers and strata to form and manifest themselves. This leads me to question what other aspects of my teaching I have yet to discover.

However, I did have significant success at Melody High. Student enrolment increased by $400 \%$ in a six year period and the Holiday and Spring Concert was selling over 500 tickets per concert. In many ways, however, I was the victim of my own success and the old adage: "be careful what you wish for, it might come true." Although it is now apparent to me through this study that a perfect storm was brewing when I took control of the reins at Melody High, I had no idea at the time. In fact, I absolutely relished the opportunity to build a music program essentially from scratch, as I did not have that opportunity in previous schools, which were well-established music programs (another example of my selfishness that manifested itself).

Initially, success was easy, as basically, there was no measuring stick to go by. As each year went by, the on and off-site concerts became bigger and better, which ultimately produced more stress, fear, and success. This was compounded by the fact that I was the only full time music teacher at the school and assumed much of the administrative duties as well, which contributed to elevated levels of stress and anxiety (Scheib, 2002). Ultimately, I could no longer maintain and manage the music program I created, which is why the flame that once burned brightly eventually burned out (Bramhall \& Ezell, 1981).

\section{Conclusion}

At the end of the day, reflective practice allows teachers to track their thoughts, feelings, and emotions throughout their teaching career. Such reflections are advantageous in the moment of writing, and are equally advantageous years later from a retrospective lens. The bottom line is that reflective practice allows practitioners to critically examine and improve their future teaching. Sharing the results of reflective practice through publications such as this one is vitally important for all practitioners. Sharing experiences creates a collective pool of ideas and thoughts that cultivate meaningful clusters of knowledge, ultimately helping to inform us about the practice of teaching music at the secondary school level specifically, and teaching in general. 
Teacher practitioners often lack a support network, particularly in non-core subjects (such as music) at secondary schools where teachers frequently operate a program on their own, as was the case with myself at Melody High. Although there was an abundance of other teachers, there were no other music teachers to share my feelings with-both successes and frustrations. This is why reflective practice is so important, as the journal writing allowed me to share my trials and tribulations with myself (Schön 1983). This is why autobiographical and phenomenological inquiry is important, as it allows the opportunity to look at your own reflections in a new and fresh manner (Gusdorf, 1980; Aoki, 1988; Grumet, 1988).

In reflection, my perceptions of what happened are much clearer and more lucid today (many years later) than they were when I was at Melody High. Re-experiencing my experience has been exceedingly beneficial and liberating, allowing me to question what I was thinking and why (Denzin, 1989; Grumet, 1980). The process of revisiting, rearranging, and reorganizing data about my experiences has increased my knowledge and shed light on my own views, values, ideologies, and representations of the world (Bullough \& Pinnegar, 2001). Much like an archeologist, I have searched and uncovered relics from my past that will assist me in my future teaching. I now feel that I have closure to the chapter of my life spent teaching music at Melody High. The final piece of the puzzle has been put in place and the big picture has revealed itself (Williamson, 1997).

Even today as a teacher educator, I have much more insight and knowledge into the demanding role of the secondary school music teacher, which I can pass on and share with my students. In sum, what I did and where I am going has ultimately been grounded in my experience at Melody High (Kitchen, Ciuffetelli-Parker, \& Pushor, 2011). 


\section{References}

Andrusyszyn, M. A., \& Davie, L. (1997). Facilitating reflection through interactive journal writing in an online graduate course. Journal of Distance Education, 12(1-2), 103126.

Aoki, T. (1988). Towards a dialectic between the conceptual world and the lived world: Transcending instrumentalism in curriculum orientation. In W. F. Pinar (Ed.), Contemporary curriculum discourses (pp. 417-436). Scottsdale, AZ: Gorsuch Scarisbrick.

Aronson, J. (1994). A pragmatic view of thematic analysis. The Qualitative Report, 2(1), Retrieved from http://www.nova.edu/ssss/QR/BackIssues/QR2-1/aronson.html

Ballantyne, J. (2007). Documenting praxis shock in early-career Australian music teachers: The impact of pre-service teacher education. International Journal of Music Education, 25(3), 181-191. doi:10.1177/0255761407083573

Bernhard, C. (2011, March). Comprehensive musicianship: Research and implications. A paper presented at the Conference on Music Learning and Teaching, Center for Applied Research in Musical Understanding at Oakland University, Rochester, MI.

Bramhall, M., \& Ezell, S. (1981). How burned out are you? Public Welfare, Winter, 23-27.

Braun, V., \& Clarke, V. (2006) Using thematic analysis in psychology. Qualitative Research in Psychology, 3(2), 77-101.

Bullough, R., \& Pinnegar, S. (2001). Guidelines for quality in autobiographical forms of selfstudy research. Educational Researcher, 30(3), 13-21.

Burke, R. J., Greenglass, E. R., \& Schwarzer, R. (1996). Predicting teacher burnout over time: Effects of work stress, social support, and self-doubts on burnout and its consequences. Anxiety, Stress, and Coping: An International Journal, 9(3), 261-275.

Carson, R. L. (2006). Exploring the episodic nature of teachers' emotions as it relates to teacher burnout (Doctoral dissertation). Retrieved from Dissertations and Theses database. (UMI No. 3232157)

Chang, M. L. (2009). An appraisal perspective of teacher burnout: Examining the emotional work of teachers. Educational Psychological Review, 21(3), 193-218. doi:10.1007/s10648-009-9106-y

Clandin, J., \& Connelly, M. (2000). Narrative inquiry: Experience and story in qualitative research. San Francisco, CA: Jossey-Bass. 
Creswell, J. (2009). Research design: Qualitative, quantitative, and mixed method approaches ( $3^{\text {rd }}$ ed.). Thousand Oaks, CA: Sage.

Creswell, J. (2012). Educational research: Planning, conducting, and evaluating quantitative and qualitative research $\left(4^{\text {th }} \mathrm{ed}\right.$.) Toronto, ON: Pearson.

Daly, J., Kellehear, A., \& Gliksman, M. (1997). The public health researcher: A methodological approach. Melbourne, Australia: Oxford University Press.

Denzin, N. (1989). The researcher: A theoretical introduction to sociological methods (3rd ed.). Englewood Cliffs, NJ: Prentice Hall.

Dewey, J. (1933) How we think: A restatement of the relation of reflective thinking to the educative process (Revised edition.). Boston, MA: D. C. Heath.

Erskine-Cullen, E. \& Sinclair, A. M. (1996). Preparing teachers for urban schools: A view from the field. Canadian Journal of Educational Administration and Policy,6. Retrieved at http://www.umanitoba.ca/publications/cjeap/articles/cullensinc.html

Friedman, M., \& Rosenman, R.H. (1974). Type A behavior and your heart. New York: Knopf Publishing.

Gordon, D. G. (1997). An investigation and analysis of environmental stress factors experienced by K-12 music teachers (Doctoral dissertation, University of Northern Iowa, 1997). Dissertation Abstracts International, 58/11, 4171.

Greenberg, J. S. (2002). Comprehensive stress management (7th ed.). New York, NY: McGraw Hill.

Grumet, M. (1980). Autobiography and reconceptualizing. Journal of Curriculum Theorizing, 2(2), 155-158.

Grumet, M. (1988). Bitter milk: Women in teaching. Boston, MA: University of Massachusetts Press.

Gusdorf, G. (1980). Conditions and limits of autobiography. In J. Olney (Ed.), Autobiography: Essays theoretical and critical (pp. 28-48). Princeton, NJ: Princeton University Press.

Haack, P. \& Smith, M. V. (2000). Mentoring new music teachers. Music Educators Journal, 87(3), 23-27.

Hamann, D. L. (1990). Burnout: How to spot it, how to avoid it. Music Educators Journal. 77(2), 30-33. doi:10.2307/3397813

Hamann, D, Daugherty, E. \& Mills, R. (1987). An Investigation of Burnout Assessment and Potential Job Related Variables among Public School Music Educators. Psychology of Music, 15(2), 128-140. 
Hamann, D. L., Daugherty, E., \& Sherbon, J. (1998). Burnout and the college music professor: An investigation of possible indicators of burnout among college music faculty members. Bulletin of the Council for Research in Music Education, 98, 1-21.

Hamann, D. L., \& Gordon, D. G. (2000). Burnout. Music Educators Journal, 87(3), 34-41.

Hewitt, D., \& Cramer, D. (2008). Introduction to research methods in psychology (2 ${ }^{\text {nd }}$ ed.). Essex, UK: Pearson Education.

Hodge, G.M., Jupp, J. J., \& Taylor, A. J. (1994).Work Stress, distress and burnout in music and mathematics teachers. British Journal of Educational Psychology, 54, 65-76.

Jorgensen, E. (2003). Transforming music education. Bloomington, IN: Indiana University Press.

Jorgensen, E. (2008). The art of teaching music. Bloomington, IN: Indiana University Pres.

Kyriacou, C. (2001). Teacher stress: Directions for future research. Educational Review, 53(1), 27- 35 .

Kitchen, J., Ciuffetelli Parker, D., \& Pushor, D. (Eds.). (2011). Narrative inquiries into curriculum making in teacher education. UK: Emerald Publishing.

Lagemann, E. C., \& Shulman, L. S. (Eds.). (1999). Issues in education research: Problems and possibilities. San Francisco, CA: Jossey-Bass.

Lee-Treweek, G., \& Linkogle, S. (2000). Danger in the field: Risk and ethics in social research. New York, NY: Routledge.

Mercer, D. (2007). The dangers of autobiographical research: A response to Purcell. Antipode A Radical Journal of Geography, 39(4), 571-578.

Merriam, S. (2002). Qualitative research in practice: Examples for discussion and analysis. New York, NY: John Wiley and Sons.

Mitchell, C., \& Coltrinari, H. (2001). Journal writing for teachers and students. In T. BarerStein \& M. Kompf (Eds.), The craft of teaching adults ( $3^{\text {rd }}$ ed.; pp. 21-38). Toronto, ON: Irwin.

Moon, J. (1999). Learning journals: A handbook for academics, students, and professional development. London, UK: Kogan Page.

Mostert, W. (2002, December). Phenomenology: Discovering new meanings of pedagogy within the lived experience. Paper presented at the Association for Active Educational Researchers. Brisbane, Australia.

Moustakas, C. (1994). Phenomenological research methods. Thousand Oaks, CA: Sage. 
Pinar, W., \& Pautz, A. (1998). Construction scars: Autobiographical voice in biography. In C. Kridel (Ed.), Writing education biography: Exploration in qualitative research (pp. 61 -72). New York, NY: Garland.

Pinar, W., Reynolds, W., Slattery, P., \& Taubman, P. (1995). Understanding curriculum: An introduction to the study of historical and contemporary curriculum discourses. New York, NY: Peter Lang.

Pio, F. (2007). A response to Cathy Benedict, "Naming our reality: Negotiating and creating meaning in the margin." Philosophy of Music Education Review, 15(2), 69-71.

Rada, R., \& Johnson-Leong, C. (2004). Stress, burnout, anxiety and depression among dentists. Journal of the American Dental Association, 135(1), 788-794.

Rice, P., \& Ezzy, D. (1999). Qualitative research methods: A health focus. Melbourne, Australia: Oxford University Press.

Ryan, C. (2009). Building strong music programs: A handbook for preservice and novice music teachers. Toronto: Rowman and Littlefield Education.

Scheib, J. W. (2002). Roles, expectations, and tension in the professional life of the school music teacher: A collective case study (Doctoral dissertation, University of Wisconsin-Madison, 2002). Dissertation Abstracts International 63(04), 1286A. (UMI No. 726442541).

Schön, D. A. (1983). The reflective practitioner: How professionals think. London, UK: Arena.

Stern, A., \& Cox, J. (1993). Teacher burnout: The dull reality. Music Educators Journal, 80(3), 33-49. doi:10.2307/3398672

Tenni, C., Smyth, A., \& Boucher, C. (2003). The researcher as autobiographer: Analysing data written about oneself. The Qualitative Report, 8(1), 1-12.

Trochim, W. (2006). Research methods knowledge base. Retrieved from http://www.social researchmethods.net/kb/qualapp.php

Vasconcelos, E. F. d. S. (2011). "I can see you": An autoethnography of my teacher- student self.

The Qualitative Report, 16(2), 414-440. Retrieved from http://www.nova.edu/ssss/QR/QR16-2/vasconcelos.pdf

Wideen, M., Mayer-Smith, J. \& Moon, B. (1998). A critical analysis of the research on learning to teach: Making the case for an ecological perspective on inquiry. Review of Education Research, 68(2), 130-178.

Williamson, A. (1997). Reflection in adult learning with particular reference to learning-inaction. Australian Journal of Adult and Community Education, 37(2), 93-99. 